\title{
Late Cretaceous stomatopods (Crustacea, Malacostraca) from Israel and Jordan
}

\author{
Cees H.J. Hof \\ Institute for Systematics and Population Biology, University of Amsterdam, P.O. Box 94766, \\ 1090 GT Amsterdam, The Netherlands
}

Keywords: Stomatopoda, Mesozoic, Cretaceous, fossils, taphonomy, taxonomy, Squilloidea, new family Ursquillidae, new genus Ursquilla

\begin{abstract}
The eryonid decapod Eryon yehoachi Remy \& Avnimelech, 1955, from the Late Cretaceous of Israel, is redescribed as a fossil stomatopod species within the new genus Ursquilla. This redescription is based on the original type specimen and two additional records from Israel and Jordan. The material allows a detailed reconstruction of the telson, the sixth abdominal tergite, and part of the uropods. The distinct telson ornamentation of these stomatopods justifies the erection of a new family within the superfamily Squilloidea.
\end{abstract}

\section{Introduction}

In 1955, Remy \& Avnimelech described Eryon yehoachi, a new species of the extinct decapod family Eryonidae. Their description was based on a single specimen from the Upper Cretaceous (Campanian) of the Ouadi Seiyal Valley in eastern Israel. The authors interpreted the fossil remains as the tergal plates of an eryonid cephalothorax showing the inner side. Although they comprehensively justified the identification of the eryonid based only on the inner side of the cephalothorax, they seemed to have no doubt about the taxonomic accuracy of their identification.

However, Glaessner (1969: 470) suggested that the description of $E$. yehoachi was actually based on a Squilla-like stomatopod telson. If Glaessner is right about the stomatopod affinities of this fossil, the material could provide important information considering the (late) Mesozoic radiation of the stomatopod taxa.

A re-study of the type specimen of $E$. yehoachi together with three previously undescribed, similar fossils from Jordan and Israel, confirms Glaessner's suggestion. The fossils, originating from three different localities (Fig. 1), allow a detailed reconstruction of the telson, the sixth abdominal tergite, and parts of the uropods. Although this analysis is based on incomplete fossil material, the telson of this Cretaceous stomatopod carries enough information to recognize a new genus within a new family. The newly recognized stomatopod sheds a fresh light on the evolution of these remarkable crustaceans.

\section{Abbreviations of depositories}

BMNH, The Natural History Museum, London GSI, Geological Survey of Israel, Jerusalem MNHN, Muséum National d'Histoire Naturelle, Paris

\section{Systematics}

Class Malacostraca Latreille, 1806

Subclass Hoplocarida Calman, 1904

Order Stomatopoda Latreille, 1817

Suborder Unipeltata Latreille, 1825

Superfamily Squilloidea Latreille, 1803

Ursquillidae Hof, new family

Diagnosis. - Moderate sized stomatopods. Telson about as long as broad with paired submedian-, intermediate-, and lateral teeth, and distinct lateral folds at one third from the anterior margin. Four rounded intermediate marginal denticles present 


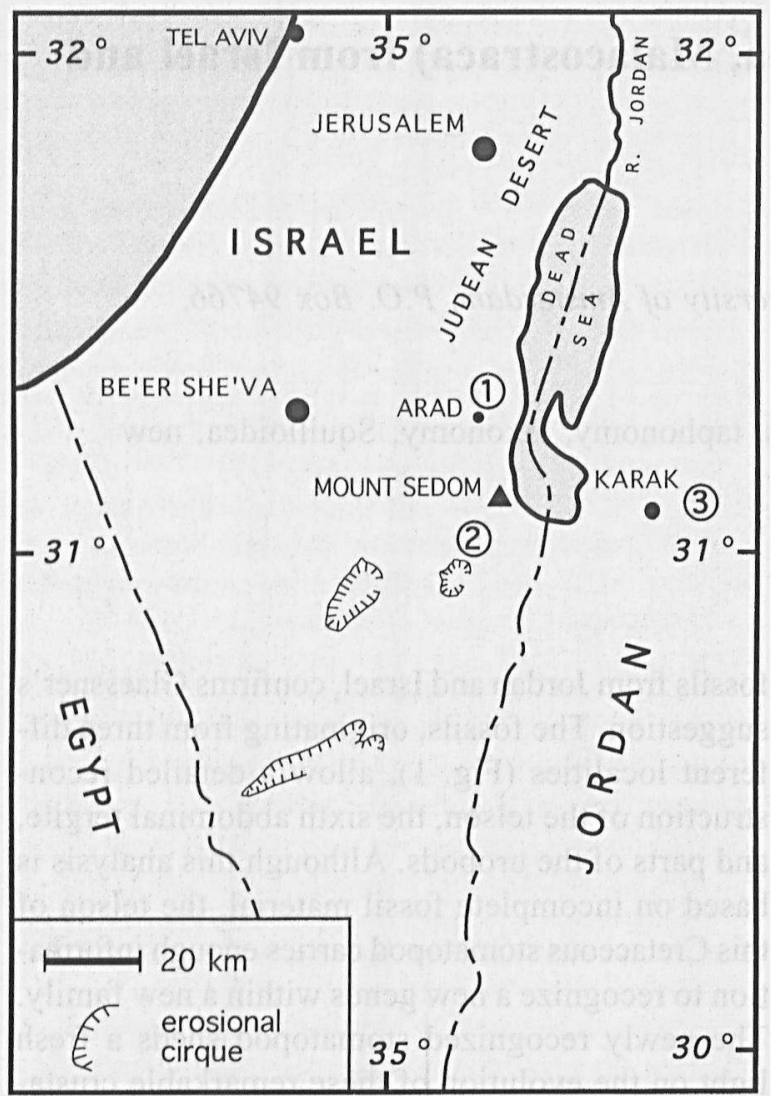

Fig. 1. Locality map for Ursquilla yehoachi (Remy \& Avnimelech, 1955): 1) Israel, in the vicinity of the city of Arad (MNHN, R. 62691), 2) Israel, north of the erosion cirque "Hamakhtesh Haquatan" (GSI, M-8113), 3) Jordan, in the vicinity of the city of Karak (BMNH, I 7316). [Disputable state boundaries are not indicated on this map.]

and a linear row of altogether four rounded submedian denticles. Telson dorsally ornamented with a median carina and paired intermediate-, lateral-, and marginal carinae. Median carina flanked by a string of tubercles. At the level of the telson's lateral folds a low transverse carina connects the lateral carina with the marginal carina. Between the lateral fold and the intermediate marginal teeth the marginal carinae carry minute, sharp, lateral tubercles. All carinae as well as the submedian marginal teeth are rounded and ornamented with a dorsal row of tubercles.

Type genus. - The new monotypic genus Ursquilla, as defined below.
Ursquilla Hof, new genus

Diagnosis. - As for family.

Type species. - Eryon yehoachi Remy \& Avnimelech, 1955, by present designation and monotypy. Originally described as the cephalothorax of an eryonid decapod.

Etymology. - The name is derived from the prefix $u r$, meaning primeval, in combination with the generic name Squilla.

Ursquilla yehoachi (Remy \& Avnimelech, 1955) new combination

(Figs. 2-4)

Synonymy. - Eryon yehoachi Remy \& Avnimelech, 1955: 311, pl. 14a; Glaessner, 1969: 470 [squillid stomatopod telson, not Eryon]; Holthuis \& Manning, 1969: 541 [may belong to genus Squilla]; Yun, 1985: 19 [referring to Holthuis, 1969; should be Holthuis \& Manning, 1969].

Material examined. - The holotype of Eryon yehoachi (MNHN, R. 62691) (Fig. 2A). This specimen shows the imprint of a telson and part of the sixth abdominal tergite on a small slab of yellowish chert. An additional specimen came from the Geological Survey of Israel (GSI, M-8113) (Fig. 2C). It concerns a relatively recent (1994) find by Dr. S. Ilani. The specimen shows the imprint of a telson, part of the sixth abdominal tergite and fragments of both the uropods on a small piece of brown chert. Two specimens on one slab originate from The Natural History Museum in London (BMNH, I 7316) (Fig. 3A). Both these specimens show the incomplete imprint of a telson, one including the remains of the sixth abdominal tergite. The two telsons are preserved at different levels on a slab of fine grained, yellowish shaly limestone. The label relates that these specimens were presented by Dr. F. Johnson through Frank T. Ellis in May 1906. In the collection of the BMNH an epoxy resin mould of the type specimen from Paris is present, indexed under number I 15472.

Localities and lithostratigraphy. - Along with the description of Eryon yehoachi, Remy \& Avnimelech (1955) provide some information on the locality and the stratigraphical position of this fossil. The specimen was found in the southern part of the Judean Desert in the Ouadi Seiyal Valley (presently named Nahal Ze'elim) along the route from Be'er She'va to Mount Sedom. The specimen label provides a coarse locality indication by referring to the coordinates 17./08. of the Israeli grid. According to Remy \& Avnimelech the specimen comes from one of the Campanian chert banks of the alternating calcareous and siliceous beds covering the southeastern flanks of the anticline of the Judean mountains. 


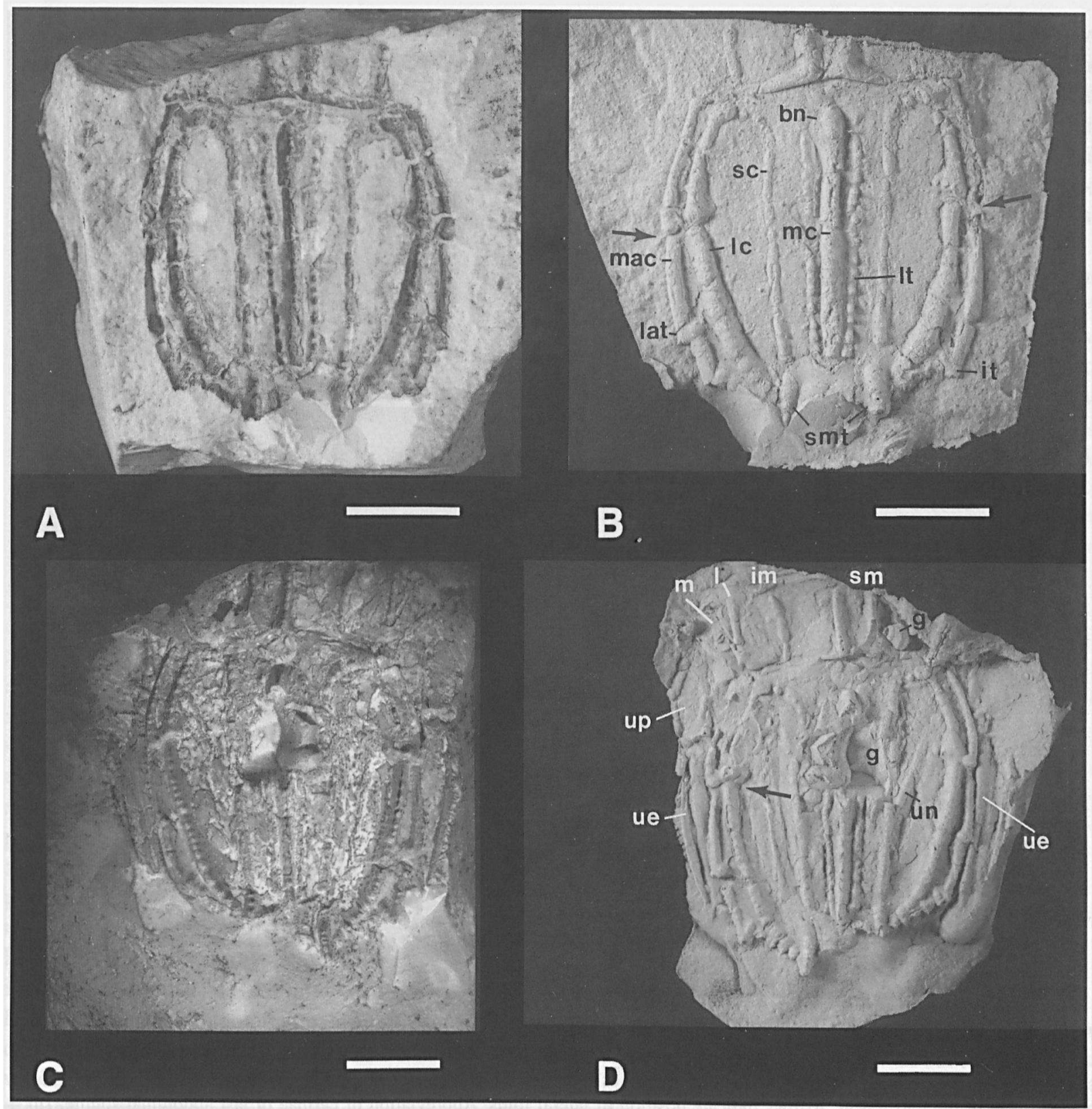

Fig. 2. Ursquilla yehoachi (Remy \& Avnimelech, 1955) fossil imprints from Israel with corresponding ammonium chloride covered peels. A, Holotype MNHN, R. 62691, showing telson and sixth abdominal somite; B, peel of holotype; C, GSI, M-8113, showing telson, sixth abdominal somite, and parts of the uropods; D, ammonium chloride covered peel of the GSI specimen. Arrows indicate position of lateral folds. Abbreviations of carinae of last abdominal somite: $\mathrm{sm}=$ submedian carinae, im $=$ intermediate carina, $1=$ lateral carina, $\mathrm{m}=$ marginal carina. Abbreviations of uropodal structures: $u p=$ uropodal protopod, ue $=$ uropodal exopod, un $=$ possible outer margin of uropodal endopod. Abbreviations for telson ornament: $\mathrm{mc}=$ median carina, $\mathrm{bn}=\mathrm{basal}$ notch, $\mathrm{lt}=\mathrm{line}$ of tubercles flanking the median carina, $\mathbf{s c}=$ submedian carina, $l c=$ lateral carina, mac $=$ marginal carina, smt $=$ submedian marginal teeth, it = intermediate marginal tooth, lat = lateral marginal tooth, $\mathrm{g}=$ gastropod shells. Scale bars all $1 \mathrm{~cm}$.

According to Dr. Zeev Lewy of the Geological Survey of Israel (pers. comm.) the fossil was most likely collected in the vicinity of the city of Arad (Fig. 1, locality 1). The chert banks to which Remy \& Avnimelech refer belong to the Chert Member (lower member) of the Mishash Formation, which ranges from the uppermost Lower Campanian into the Middle Campanian. Biostratigraphically these banks are within the ammonite Hoplitoplacenticeras marroti Zone (Reiss et al., 1986). 


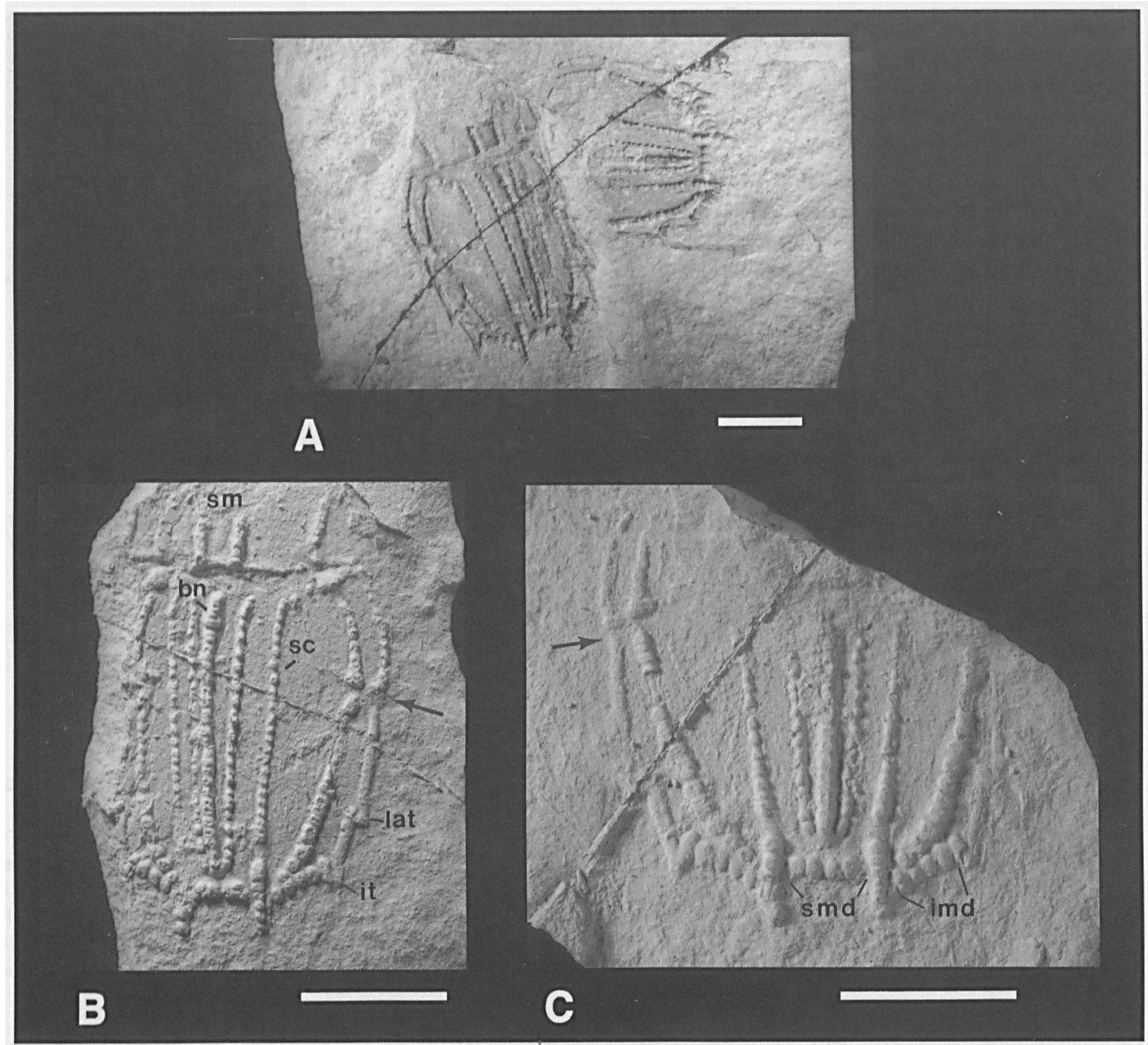

Fig. 3. Two Ursquilla yehoachi (Remy \& Avnimelech, 1955) fossil imprints from Jordan with corresponding ammonium chloride covered peels. A, BMNH, I 7316, showing a telson with attached sixth abdominal somite and the posterior half of a telson at a slightly higher level; B, ammonium chloride covered peel of the telson with attached sixth abdominal somite; C, ammonium chloride covered peel of the half telson. Arrows indicate position of lateral folds. Abbreviation of carinae of last abdominal somite: sm $=$ submedian carinae. Abbreviations for telson ornament: $b n=$ basal notch median carina, $s c=$ submedian carina, lat $=$ lateral marginal tooth, it = intermediate marginal tooth, imd = intermediate marginal denticles, smd = submedian marginal denticles. Scale bars all 1 $\mathrm{cm}$.

The GSI specimen originates from the same Chert Member of the Mishash Formation; only this specimen was found at the northern flank of the Hazera Anticline, north of the erosion cirque "Hamakhtesh Haquatan" (Fig. 1, locality 2). The specimen label refers to the coordinates $175 / 049$ of the Israeli grid.

Information on the BMNH specimens is very sparse. The label just mentions "formation Upper Cretaceous" and "locality Kerak, Moab". Apparently these specimens originate from Senonian outcrops near the Jordanian city of Karak in the Moab region (Fig. 1, locality 3 ). Most probably the specimens were found east of Karak in outcrops of the Amman Silicified Limestone Formation (pers. comm. Zeev Lewy).

Description. - Three of the four imprints show fragmented remains of the last abdominal tergite. This tergite is ornamented with paired submedian-, intermediate-, lateral-, and marginal carinae. The submedian carinae are sharp, straight, and provided with a dorsal row of tubercles (Figs. 2D; 
3B). Their height gradually increases towards the posterior margin of the tergite where they end abruptly. The intermediate carinae are less pronounced, slightly curved, and directed slightly oblique anterolaterally (Fig. 2D). These carinae appear to be inflated medially. As is the case with the submedian carinae, the intermediate carinae are provided with a dorsal row of tubercles. Lateral and marginal carinae are only preserved in GSI M-8113, although incompletely (Fig. 2D). The lateral carinae are straight and relatively sharp. These carinae are also ornamented with a row of tubercles. Thin marginal carinae are present. These marginal carinae are positioned obliquely towards the posterior margin of the tergite where they fuse with the lateral carinae. At this junction a small posteriorly directed marginal spine is present.

GSI M-8113 is the only specimen that shows remains of the uropods (Fig. 2C, D). The uropodal protopod structures that can be recognized include a curved lateral or marginal carina, a bifurcated median carina that is partially ornamented with small dorsal tubercles, and a proximal carina paralleling the lateral margin of the sixth abdominal tergite (Figs. 2D; 4). The uropodal exopod seems unisegmented although the presence of a second segment cannot be excluded due to the poor preservation of the uropods. The exopod is about four to five times as long as it is broad. It is not possible to determine the overall shape of this segment in full detail; only fragments of thickened lateral margins are visible. The inner margin appears inflated and carries a dorsal row of small tubercles. Distally at least two lateral spines are present. The outer margin is more flattened and, based on the visible remains, at least the distal two third is ornamented with a row of lateral spines.

Only tiny fragments of the uropodal endopods are preserved (Fig. 2D). The outer margin seems inflated, the inner margin carries a fringe of setae.

The telson is about as long as broad and has the overall shape of a rectangle with convex lateral margins. Three pairs of marginal teeth can be distinguished: submedians, intermediates, and laterals (Figs. 2B; 3B). The submedian teeth are the most prominent, clearly protruding from the posterior margin of the telson. These teeth are inflated over their entire length and dorsally ornamented with four to six tubercles, decreasing in size distally (best in Fig. 3). The intermediate and lateral teeth are less pronounced. Both are inflated but not provided with tubercles. Halfway between the lateral teeth and the anterior margin of the telson a marginal wrinkle reflects the presence of a prominent lateral crease or fold on the telson (arrows in Figs. 2B, $D$; 3B, C).

Between the submedian and intermediate teeth there are prominent marginal denticles. A linear row of four equally sized submedian denticles is present, arranged in symmetrical pairs (Fig. 3C). Between the submedian and intermediate teeth, a linear row of four intermediate, equally sized denticles is present (Fig. 3C). Both submedian and intermediate denticles are rounded and inflated. The row of submedian denticles is positioned more proximally as compared to the two rows of intermediate denticles.

From the intermediate teeth up to the anterior edge of the telson the margin is inflated forming rounded marginal carinae. These carinae are dorsally ornamented with small tubercles, on the sections between the anterior edge and the lateral wrinkles more pronounced than on the sections between the lateral wrinkles and the intermediate teeth. The sections between the lateral wrinkle and the intermediate teeth carry minute sharp, lateral tubercles (best visible on right side of Fig. 2D).

The dorsal ornament on the telson is very distinctive (indicated in Fig. 2B). A robust rounded median carina is present. This carina spans the entire length of the telson, starting a few millimetres from the anterior margin of the telson to end a few millimetres in front of the row of submedian denticles. The anterior onset of the carina is rounded and slightly inflated, forming a basal notch (Figs. 2B; 3B). Posteriorly the carina ends gently. The relative sharpness of the carina seems to increase posteriorly, and a median row of small tubercles is present over its entire length, including the basal notch. The median carina is flanked by tubercles. These tubercles are organized in straight rows, starting anterior of the basal notch of the median carina and meeting in a small arch that encloses the posterior end of the median carina.

Paired submedian carinae are situated about one third of the way from the median carina. These 
carinae are straight and slightly diverging anterolaterally. The carinae are only slightly elevated but are profoundly ornamented with tubercles (Fig. 3B). Posteriorly these carinae seem to form a continuation of the submedian marginal teeth although there is a clear gap between both these elevated structures. The anterior tip of the submedian carinae curves laterally. A solitary tubercle between the anterior end of the submedian carinae and the anterior onset of the lateral carinae (best in Fig. 2D), gives the impression of a curved connection between these structures.

The lateral carinae are distinctive and, as all other carinae of this specimen, ornamented with a dorsal row of tubercles. Anteriorly the lateral carinae start as transverse oriented ovate notches. The carinae that emanate from these notches run parallel to the marginal carinae and end at the base of the submedian marginal teeth. However, these carinae do not form continuous structures. About one third from the anterior margin of the telson there is a fissure in the lateral carina where a low transverse carina connects the lateral carina with the marginal carina. At this point there is also a low mesiad protrusion of the lateral carina. This complex of structures gives the impression of a distinctive lateral crease on the telson. Following the lateral carinae further posteriorly, there are two other low fissures. These fissures are positioned in line with the lateral and intermediate marginal teeth.

Remarks. - There is some variation in the shape of the telsons. The telsons from Jordan are mord elongated and their carinae less inflated compared to the Israeli telsons. However, these two differences could be preservational artefacts.

The number of tubercles on the various carinae also seems to vary, but a detailed comparison of the specimens is difficult because the tuberculate rows and carinae are often disturbed. On the Jordanian telsons the submedian teeth are ornamented with six dorsal tubercles, while the telsons from Israel only seem to carry four or five tubercles. The rows of tubercles flanking the median carina in the Israeli holotype MNHN, R. 62691 count about 18 tubercles per row while the complete Jordanian telson of BMNH, I 7316 shows about 25 tubercles. These differences are partly due to the bipolar nature of some of the tubercles on the Jordanian telsons. The tubercles seem to consist of a large tubercle with a smaller adjacent tubercle, or simply two smaller tubercles instead of one "normal" tubercle.

It looks like one of the uropodal endopods in GSI, M-8113 is preserved underneath the surface of the telson. A margin is visible ("un" in Fig. 2D) and mediad of this margin some very tiny fragments of possibly a setal fringe. However, because of this remarkable preservation these characters should be considered very carefully.

Although the material is well preserved, fine details were lost in the process of fossilization. It could be that there are small movable or fixed apices on the submedian teeth. Especially the telsons from Jordan seem to carry cuticular remains of very small apical spines. However, the evidence is not convincing since the rest of the teeth are not preserved in fine detail.

The presence of spines on the distal end of the uropodal exopod is based on wet observations in a smooth, circular excavation on GSI, M-8113 (left side Fig. 2C). The rounded apex of the uropodal exopod visible on the latex peel (right side Fig. 2D) is thus a preparational artefact.

Taphonomy. - The finds of only a telson with one or more attached abdominal somites are common in the stomatopod fossil record (Hof \& Briggs, 1997). The specimens of Ursquilla yehoachi are apparently transported fragments of decayed animals. The GSI specimen carries two gastropods, one in the centre of the telson and one on the sixth abdominal somite (Fig. 2D). These gastropods were apparently scavenging or grazing on the stomatopod remains or just coincidentally fossilized on the telson. Commensal gastropods on extant stomatopods only attach to the abdominal or thoracic ventral side of their host (e.g. Rosewater, 1969; Reaka, 1978).

All the specimens of $U$. yehoachi are no real imprints but external dorsal moulds. Mainly on MNHN, R. 62691 and BMNH, I 7316 there are many tiny fragments of mineralized cuticle visible, especially of the carinae and tubercles. Under high magnification $(50 x)$ the laminated composition of the cuticle is clearly visible. Scanning Electron Microscope observations could reveal the fine details of these cuticular remains. 


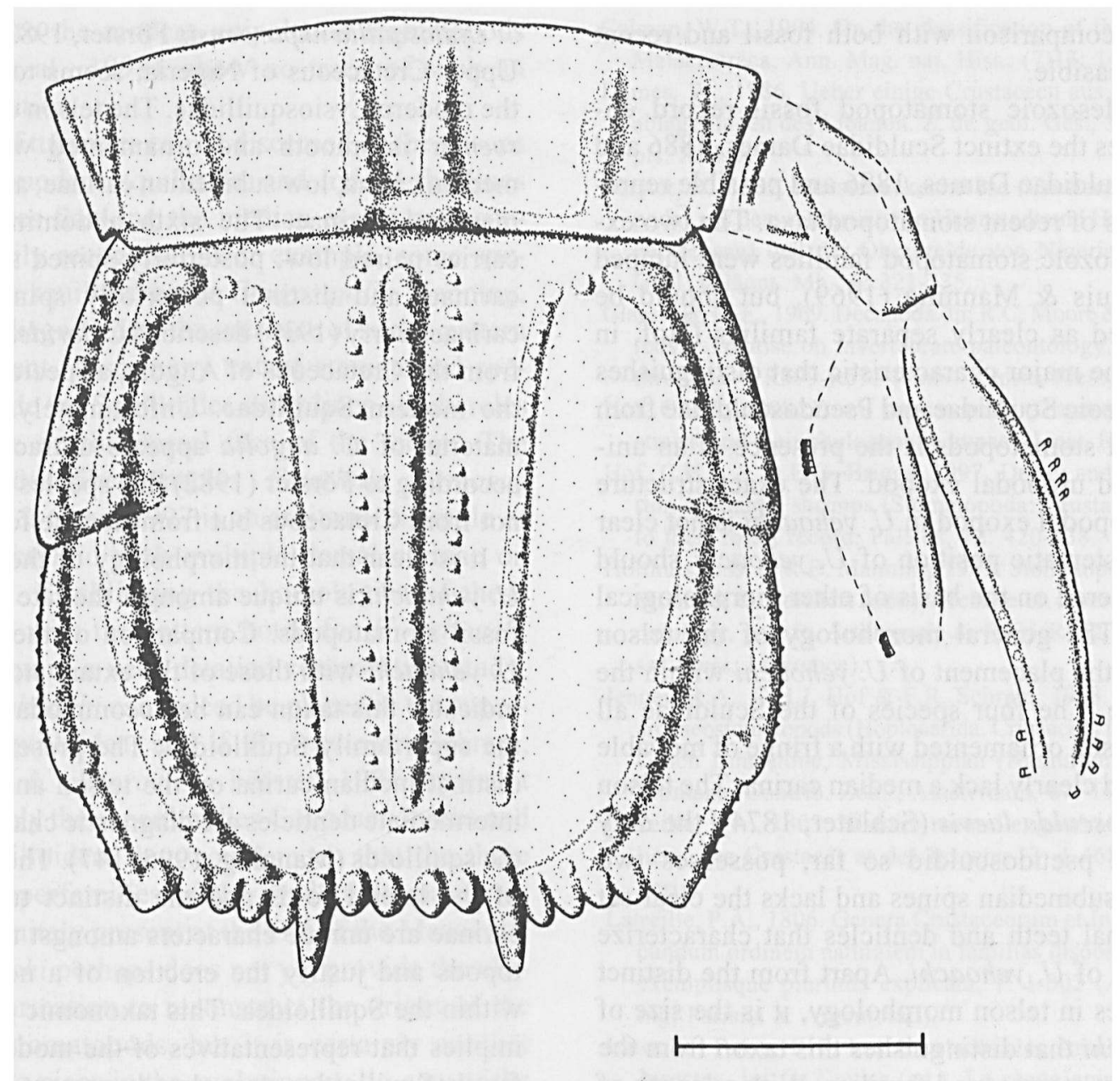

Fig. 4. Reconstruction of the telson and the sixth abdominal tergite of Ursquilla yehoachi (Remy \& Avnimelech, 1955). Of the uropods only the visible fragments are reconstructed; the possible outline is indicated by dotted lines. Scale bar is $1 \mathrm{~cm}$.

Measurements. - The length of the telson is measured medially from the anterior margin to a hypothetical line over the tips of the submedian denticles. Telson width is the greatest width. The telson of MNHN, R. 62691 is $3 \mathrm{~cm}$ long and $3.1 \mathrm{~cm}$ wide. The telson of GSI, M-8113 is about $3.2 \mathrm{~cm}$ long and $3 \mathrm{~cm}$ wide; the sixth abdominal somite of this specimen is $1 \mathrm{~cm}$ high and about $3.2 \mathrm{~cm}$ broad. The most complete telson on BMNH, I 7316 is $2.4 \mathrm{~cm}$ long and estimated $2.4 \mathrm{~cm}$ wide; the incomplete telson has the same dimensions.

Assuming that these stomatopods had the body proportions of a standard squilloid such as Squilla mantis (Linnaeus, 1758), and $2.8 \mathrm{~cm}$ is taken as the average length of Ursquilla yehoachi's telson, a corse estimation of the total length would be 17 or $18 \mathrm{~cm}$ (total length as defined by Manning, 1969).

\section{Discussion}

A reconstruction of the telson and the sixth abdominal tergite of Ursquilla yehoachi is offered in Fig. 4. Of the uropods only the visible remains are drawn.

The description of $U$. yehoachi is based on only the posterior part of these stomatopods. Fortunately, these parts carry most of the crucial diagnostic characters used in stomatopod taxonomy and a 
detailed comparison with both fossil and recent taxa is feasible.

The Mesozoic stomatopod fossil record encompasses the extinct Sculdidae Dames, 1886 and Pseudosculdidae Dames, 1886 and possible representatives of recent stomatopod taxa. The two extinct Mesozoic stomatopod families were lumped by Holthuis \& Manning (1969), but should be considered as clearly separate families (Hof, in press). The major characteristic that distinguishes the Mesozoic Sculdidae and Pseudosculdidae from the extant stomatopods is the presence of an unisegmented uropodal exopod. The exact structure of the uropodal exopod in $U$. yehoachi is not clear so the systematic position of $U$. yehoachi should be considered on the basis of other morphological aspects. The general morphology of the telson excludes the placement of $U$, yehoachi within the Sculdidae. The four species of the Sculdidae all have a telson ornamented with a fringe of movable spines and clearly lack a median carina. The telson of Pseudosculda laevis (Schlüter, 1874), the only described pseudosculdid so far, possesses two movable submedian spines and lacks the clear set of marginal teeth and denticles that characterize the telson of $U$. yehoachi. Apart from the distinct differences in telson morphology, it is the size of $U$. yehoachi that distinguishes this taxon from the two extinct stomatopod families. With a length of around 17 or $18 \mathrm{~cm}, U$, yehoachi is a real giant compared to the Sculdidae with their average length of about $3 \mathrm{~cm}$ (own observations) and the slightly larger Pseudosculdidae that range between 3 to 4 cm (own observations).

Dames (1886) suggested that modern stomatopods were present at the end of the Cretaceous. This remark was based solely on the record of Squilla cretacea Schlüter, 1868, from the Upper Cretaceous of Sendenhorst in Germany. This fossil stomatopod is poorly described and the accompanying drawing is not very clear. Attempts to trace the original material have failed so far. More recent Mesozoic fossil stomatopod records are known from Schram (1968) who described Paleosquilla brevicoxa from the Cretaceous of Colombia. This stomatopod seems to resemble the modern Gonodactyloidea. However, the telson of this species was not preserved.
Lysiosquilla nkporoensis Förster, 1982, from the Upper Cretaceous of Nigeria, seems to represent the modern Lysiosquillidae. The telson of $L$. nkporoensis is smooth and ornamented with a low median carina, low submedian carinae, and distinct marginal carinae. The sixth abdominal somite carries paired low, posteriorly spined submedian carinae, and distinct posteriorly spined lateral carinae. Berry (1939) described Chloridella angolia from the Cretaceous of Angola, a species allied to the modern Squillidae. Unfortunately, the type material of C. angolia appears untraceable and according to Förster (1982) this species originates not from Cretaceous but from Eocene formations.

It is clear that the morphology of the telson of $U$. yehoachi is unique amongst the late Mesozoic tossil stomatopods. Comparison of the telson of $U$. yehoachi with those of the extant stomatopods indicates this taxon can be accommodated within the superfamily Squilloidea. The presence of the distinct median carina on the telson and the four intermediate denticles are diagnostic characters for the squilloids (Manning, 1995: 147). The presence of the lateral folds and the distinct tuberculate carinae are unique characters amongst the stomatopods and justify the erection of a new family within the Squilloidea. This taxonomic placement implies that representatives of the modern superfamily Squilloidea were already present by the end of the Mesozoic.

The value of $U_{\text {. yehoachi }}$ in a phylogenetic reconstruction of the stomatopods is unfortunately limited. The incompletely preserved uropods and the lack of the entire anterior portions of the body, especially the second thoracopods, prevent an exact positioning of this animal in the evolutionary history of the stomatopods. Within the Squilloidea, however, the discovery of this fossil species might provide information useful towards polarizing certain characters of the superfamily. Some genera within the Squilloidea possess so-called prelateral lobes. These pre-lateral lobes could be remnants of the lateral folds that are so obviously developed in $U$. yehoachi. These distinct lateral folds themselves raise the issue of a possible twosegmented origin of the modern stomatopod telson, i.e., the fusion of a telson with a seventh abdominal somite. However, the Paleozoic Tyrannophontidae, 
ancestral to the modern unipeltatan stomatopods (Jenner et al., 1998), show no trace of such an amalgamation.

Lines of tubercles can be discerned on the telsons of many modern squilloids, and indeed the lines of tubercles flanking the median carina are especially easily recognized. For example, some species of the squilloid genus Erugosquilla Manning, 1995 are diagnosed by the presence of such a pattern of ornament. Also many extant stomatopod species outside the Squilloidea carry lines of tubercles or carinae on the dorsal face of the telson. The recently described species Faughnia formosae Manning \& Chan, 1997 is an arbitrary example of a gonodactyloid with multiple dorsal carinae on its telson. Establishing the homologies of these structures with the pattern noted for $U$. yehoachi would require a very detailed comparative study.

If $U$. yehoachi can indeed be placed in the superfamily Squilloidea, and if $P$. brevicoxa Schram, 1968 and L. nkporoensis Förster, 1982 represent respectively the superfamilies Gonodactyloidea and Lysiosquilloidea, this would mean that the three largest superfamilies of the modern stomatopods were definitely present at the end of the Mesozoic. $U$. yehoachi perhaps does not yet provide the ultimate information to reconstruct the origin of the modern stomatopods, but it is certainly another interesting piece in the evolutionary jig-saw of the stomatopods.

\section{Acknowledgements}

For providing me with the specimens I wish to thank Agnès $\mathrm{L}$. Rage (Institut de Paléontologie, MNHN, Paris), David N. Lewis (Collections Manager, Fossil Invertebrates and Plants, Department of Palaeontology, BMNH, London), and Zeev Lewy (GSI, Jerusalem). Zeev Lewy also helped me with the description of the localities and the stratigraphical data. I thank John Jagt for acting as an intermediary in the transport of the GSI specimen to Amsterdam. Frederick R. Schram and Lipke B. Holthuis are thanked for critically reviewing the manuscript.

\section{References}

Berry, C. T., 1939. A summary of the fossil Crustacea of the order Stomatopoda, with a description of a new species from Angola. Am. Midl. Nat, 21: 461-471.
Calman, W.T., 1904. On the classification of the Crustacea Malacostraca. Ann. Mag. nat. Hist., (7)13: 144-158.

Dames, W., 1886. Ueber einige Crustaceen aus den Kreídeablagerungen des Libanon. Z. dt. geol, Ges., 38: 551-575, pls. XIII-XV.

Förster, R., 1982. Heuschreckenkrebse (Crustacea, Stomatopoda) aus dem Alttertiär von Helmstedt und Handorf (Niedersachsen) und der Oberkreide von Nigeria. Neues Jb. Geol. Palẫont. Mh., 6: 321-335.

Glaessner, M.F., 1969, Decapoda. In: R.C. Moore \& C. Teichert (eds.), Treatise on invertebrate paleontology, part R, Arthropoda 4: R399-R533 (Univ. Kansas Press, Lawrence).

Hof, C.H.J., 1998. Fossil stomatopods (Crustacea: Malacostraca) and their phylogenetic impact. J. nat. Hist. In press.

Hof, C.H.J. \& D.E.G. Briggs, 1997. Decay and mineralization of mantis shrimps (Stomatopoda: Crustacea) - a key to their fossil record. Palaios, 12: 420-438.

Holthuis, L.B. \& R.B. Manning, 1969. Stomatopoda. In: R.C. Moore \& C. Teichert (eds.), Treatise on invertebrate paleontology, part R, Arthropoda 4: R535-R552 (Univ. Kansas Press, Lawrence).

Jenner, R.A., C.H.J. Hof \& F.R. Schram, 1998. Palaeo- and archaeostomatopods (Hoplocarida, Crustacea) from the Bear Gulch Limestone, Mississippian (Namurian), of central Montana. Contrib. Zool., Amsterdam, 67: 155-185.

Latreille, P.A., 1803. Hîstoire naturelle, générale et particulière, des Crustacés et des Insectes, 3: 1-468 (F. Dufart, Paris).

Latreille, P.A., 1806. Genera Crustaceorum et Insectorum secundum ordinem naturalem in familias disposita, iconibus exemplisque plurimis explícata, 1: 1-302 (Amand Koenig, Parisiis \& Argentorati).

Latreille, P.A., 1817. Les Crustacếs, les Arachnides et les Insectes. In: G. Cuvier (ed.), Le règne animal distribué d'après son organisation, pour servir de base à l'histoire naturelle des animaux et d'introduction à l'anatomie comparée. Ed. 1, 3: i-xxix, 1-653 (Deterville, Paris).

Latreille, P.A., 1825. Familles naturelles du règne animal, exposées succinctement et dans un ordre analytique, avec l'indication de leurs genres: 1-570 (J.B. Baillière, Paris).

Linnaeus, C., 1758. Systema naturae per regna tria naturae, secundum classes, ordines, genera, species, cum characteribus, differentiis, synonymis, locis. Ed. 10, 1: i-iii, 1824 (Laurentii Salviî, Holmiae).

Manning, R.B., 1969. Stomatopod Crustacea of the Western Atlantic. Stud. trop. Oceanogr., 8: i-viii, 1-380 (Miami Press).

Manning, R.B., 1995. Stomatopod Crustacea of Vietnam: The legacy of Raoul Serène. Crust. Res., special nùmber 4: 1viii, 1-339 (The Carcinological Society of Japan, Tokyo).

Manning, R.B. \& T.-Y. Chan, 1997. The genus Faughnia from Taiwan, with the description of a new species (Stomatopoda: Parasquillidae). J. crust. Biol, 17: 546-554.

Reaka, M.L., 1978. The effects of an ectoparasitic gastropod, Caledoniella montrouzieri, upon moulting and reproduction of a stomatopod crustacean, Gonodactylus viridis. Veliger, 21: 252-254. 
Reiss, Z, A. Almogi-Labin, Zx Lewy \& S. Moshkovitz, 1986. Biostratigraphic datums in the Senonian of Israel. Proc. K. Ned. Akad. Wet., (B) 89; 95-104.

Remy, J.-M, \& M. Avnimelech, 1955. Eryon yehoachi nov. sp. et Cenomanocarcinus cf. vanstraeleni Stenzel. Crustacés Décapodes du Crétacé supérieur de 1'état d"Israël. Bull. Soc. géol. France, (6) 5: 311-314, pl. XIXa.

Rosewater, J., 1969. Gross anatomy and classification of the commensal gastropod, Caledoniella montrouzieri Souverbie, 1869. Veliger, 11: 345-350, pl. 55.

Schlüter, $\mathrm{Cl}$, 1868. Stomatopoda. In: W. von der Marck \& Cl. Schlüter, Neue Fische und Krebse aus der Kreide von Westphalen. Palaeontographica, 15: 303-304, pl. XXIV.
Schlüter, $\mathrm{Cl}$, 1874. Ueber einige jurassische Crustaceen-Typen in der oberen Kreide I; Fossile Krebse des Libanon. Sitzungsberichte herausgegeben vom naturhistorischen Verein der Preussischen Rheinlande und Westfalens, 31: 41-45, pl. III.

Schram, F.R., 1968. Paleosquilla gen. nov. - a stomatopod (Crustacea) from the Cretaceous of Colombia. J. Paleontol., 42: 1297-1301.

Yun, H., 1985. Some fossil Squillidae (Stomatopoda) from the Pohang Tertiary Basin, Korea. J. paleont. Soc. Korea, 1: 19-31.

Received: 18 December 1997 